\title{
PENATALAKSANAAN ENDOMETRIOSIS
}

\author{
Erna Suparman \\ Bagian/SMF Obstetri dan Ginekologi Fakultas Kedokteran Universitas Sam Ratulangi \\ RSUP Prof. Dr. R. D. Kandou Manado \\ Email: ernasuparman@yahoo.com
}

\begin{abstract}
Endometriosis is characterized by the occurence of endometrial cells outside the uterine cavity. Endometrial tissue in the pelvic cavity increases the activity of macrophages to phagocyte endometrial tissue debris and influences intrauterine implantation. Bleeding, arising from endometriosis lesions, will lead to adhesions with surrounding tissues, resulting in changes of tubal motility, pain, and infertility. Laparoscopy examination is necessary for confirming the diagnosis. While transvaginal ultrasound is famous for its accuracy, it provides just a little help for finding cystic masses in the parametrium. Nowadays, the treatment of endometriosis with estrogen is begining to be abandoned because it may cause endometrial hyperplasia that can develop into endometrial cancer. Albeit, danazol treatment succeeds due to its hormonal and immunologic effects. The first-line of therapy given for reducing pelvic pain is NSAIDs or oral contraceptives. If this fails, a GnRH agonist is given in combination with estrogen and progestin as an add-back therapy, otherwise an operative laparoscopy has to be done. Concerning the degree of severe and extensive endometriosis, atraumatic surgery is the main option. The induction of ovulation shows a satisfactory result. Randomized trials using the GnRH agonist administration associated with the hormones (FSH and LH), clomiphene citrate, and intrauterine insemination, showed an increased incidence of pregnancy compared to those without therapy.
\end{abstract}

Key words: endometriosis, hormones, pain, infertility

\begin{abstract}
Abstrak: Endometriosis ditandai adanya sel-sel endometrium di luar kavum uteri. Jaringan endometrium di dalam rongga pelvis akan meningkatkan aktifitas makrofag untuk memfagositosis debris jaringan endometriosis serta mempengaruhi nidasi intrauterin. Perdarahan yang timbul dari lesi endometriosis akan menyebabkan perlekatan dengan jaringan sekitarnya, yang berakibat perubahan motilitas tuba, nyeri, dan infertilitas. Laparoskopi sangat diperlukan untuk diagnosis endometriosis. USG transvaginal yang tersohor karena akurasinya hanya sedikit membantu menemukan lesi di daerah parametrium. Dewasa ini, pengobatan endometriosis dengan estrogen mulai ditinggalkan karena mengakibatkan hiperplasia endometrium yang dapat berkembang menjadi kanker endometrium. Keberhasilan pengobatan dengan danazol disebabkan karena efek hormonal dan imunologiknya. Terapi lini pertama pada nyeri pelvis ialah NSAID atau kontrasepsi oral. Bila gagal, diberikan agonis GnRH dikombinasi dengan estrogen dan progestin addback therapy, atau laparoskopi operatif. Pada endometriosis derajat berat dan luas, pembedahan atraumatik merupakan pilihan utama. Induksi ovulasi memberikan hasil yang cukup memuaskan. Randomized trials pada pemberian GnRH agonis dengan hormon FSH dan LH, clomifen sitrat, serta inseminasi intrauterin, memperlihatkan peningkatan angka kehamilan dibandingkan pada yang tanpa terapi.
\end{abstract}

Kata kunci: endometriosis, hormon, nyeri, infertilitas 
Endometriosis merupakan kondisi medis pada wanita yang ditandai dengan tumbuhnya sel-sel endometrium di luar kavum uteri. Sel-sel endometrium yang melapisi kavum uteri sangat dipengaruhi hormon wanita. Dalam keadaan normal, sel-sel endometrium kavum uteri akan menebal selama siklus menstruasi berlangsung agar nantinya siap menerima hasil pembuahan sel telur oleh sperma. Bila sel telur tidak mengalami pembuahan, maka sel-sel endometrium yang menebal akan meluruh dan keluar sebagai darah menstruasi. ${ }^{1,2}$

Pada endometriosis, sel endometrium yang semula berada dalam kavum uteri berpindah dan tumbuh di luar kavum uteri. Sel-sel dapat tumbuh dan berpindah ke ovarium, tuba Falopii, belakang kavum uteri, ligamentum uterus, bahkan dapat sampai ke usus dan vesika urinaria. Pada saat menstruasi berlangsung, sel-sel endometrium yang berpindah ini akan mengelupas dan menimbulkan perasaan nyeri di sekitar panggul. ${ }^{3-7}$

Endometriosis akan menyebabkan perubahan pada lingkungan fisiologik dalam pelvis. Adanya jaringan endometrium di dalam pelvis akan mempengaruhi respon sel-sel imun di daerah sekitar alat genitalia. Perubahan respon imunologik dapat mempengaruhi nidasi intrauterin dan perkembangan awal dari fetus. Tubuh akan merespon dengan terjadinya penolakan hasil konsepsi tersebut. Sebagai hasil akhir, nidasi sering tidak berhasil dan terjadi penghambatan pertumbuhan fetus intrauterin; juga bisa terjadi nidasi diluar intrauterin sehingga terjadi kehamilan ektopik. $^{8}$

Endometriosis pelvis akan meningkatkan aktivitas makrofag baik dalam pelvis untuk memfagositosis debris dan jaringan endometriosis. Aktivitas makrofag juga terjadi intrauterin dan pada tuba yang menyebabkan peningkatan aktivitas fagositosis sperma. Perdarahan yang timbul dari lesi endometriosis akan menyebabkan pertumbuhan jaringan di dalam pelvis, terjadi perlengketan dengan jaringan sekitarnya yang berakibat perubahan motilitas tuba, dispareunea dan infertilitas. ${ }^{1,8}$
Umumnya endometriosis muncul pada usia reproduktif. Angka kejadian endometriosis mencapai $5-10 \%$ pada wanita umumnya, dan lebih dari $50 \%$ terjadi pada wanita perimenopause. Gejala endometriosis sangat tergantung pada letak sel-sel endometrium. Keluhan yang paling menonjol ialah nyeri pada panggul, sehingga hampir 71-87\% kasus di diagnosis akibat keluhan nyeri kronis hebat pada saat haid, dan hanya $38 \%$ yang muncul akibat keluhan infertil. Juga pernah dilaporkan terjadinya endometriosis pada masa menopause, dan bahkan terjadi pada $40 \%$ pasien histerektomi. Beberapa studi juga mengatakan bahwa wanita Jepang mempunyai prevalensi yang lebih besar dibandingkan wanita Kaukasia. Selain itu juga $10 \%$ endometriosis ini dapat muncul pada yang mempunyai riwayat endometriosis di keluarganya. ${ }^{9}$

\section{ETIOLOGI}

Sampai saat ini etiologi endometriosis yang pasti belum jelas. Beberapa ahli mencoba menerangkan kejadian endometriosis dengan berbagai teori, yakni teori implantasi dan regurgitasi, metaplasia, hormonal, serta imunologik. ${ }^{1,8}$

Teori implantasi dan regurgitasi mengemukakan adanya darah haid yang dapat mengalir dari kavum uteri melalui tuba Falopii, tetapi tidak dapat menerangkan terjadinya endometriosis diluar pelvis. Teori metaplasia menjelaskan terjadinya metaplasia pada sel-sel coelom yang berubah menjadi endometrium. Menurut teori ini, perubahan tersebut terjadi akibat iritasi dan infeksi atau pengaruh hormonal pada epitel coelom. Dari aspek endokrin, hal ini bisa diterima karena epitel germinativum ovarium, endometrium, dan peritoneum berasal dari epitel coelom yang sama. ${ }^{1,8,10}$

Yang paling dapat diterima yakni teori hormonal, yang berawal dari kenyataan bahwa kehamilan dapat menyembuhkan endometriosis. Rendahnya kadar FSH (folicle stimulating hormone), LH (luteinizing hormone), dan estradiol (E2) dapat menghilangkan endometriosis. Pemberian steroid seks juga dapat menekan sekresi FSH, LH, 
dan E2. Pendapat yang sudah lama dianut ini mengemukakan bahwa pertumbuhan endometriosis sangat tergantung pada kadar estrogen dalam tubuh, tetapi akhir-akhir ini mulai diperdebatkan. Menurut Kim et al, kadar E2 ditemukan cukup tinggi pada kasus-kasus endometriosis. Olive (1990) menemukan kadar E2 serum pada setiap kelompok derajat endometriosis terdapat dalam batas normal. Keadaan ini juga tidak bergantung pada beratnya derajat endometriosis, dan makin menimbulkan keraguan mengenai penyebab sebenarnya dari endometriosis. ${ }^{4,5,7}$ Bila dianggap perkembangan endometriosis bergantung pada kadar estrogen dalam tubuh, seharusnya terdapat hubungan bermakna antara beratnya derajat endometriosis dengan kadar E2. Di lain pihak, bila kadar E2 tinggi dalam tubuh maka senyawa ini akan diubah menjadi androgen melalui proses aromatisasi, yang berakibat kadar testosteron (T) akan meningkat. Kenyataan pada penelitian tersebut, kadar $\mathrm{T}$ tidak berubah secara bermakna menurut beratnya penyakit, bahkan dalam cairan peritoneal terlihat kadarnya cenderung menurun seirama dengan E2. Berdasarkan hal tersebut maka dapat dikatakan bahwa memberatnya endometriosis tidak murni tergantung estrogen saja. ${ }^{7}$

Teori endometriosis dapat dikaitkan dengan aktivitas sistem imun. Teori imunologik menerangkan bahwa secara embriologik, sel epitel yang membungkus peritoneum parietal dan permukaan ovarium memiliki asal yang sama; oleh karena itu selsel endometriosis akan sejenis dengan mesotel. Telah diketahui bahwa CA-125 merupakan suatu antigen permukaan sel yang semula diduga khas untuk ovarium. Endometriosis merupakan proses proliferasi sel yang bersifat destruktif dan akan meningkatkan kadar CA-125. Oleh karena itu, antigen ini dipakai sebagai penanda kimiawi. ${ }^{11-13}$

Banyak peneliti yang berpendapat bahwa endometriosis merupakan penyakit autoimun karena memiliki kriteria yang cenderung bersifat familiar, menimbulkan gejala klinik yang melibatkan banyak organ, dan menunjukkan aktivitas sel B poliklonal. ${ }^{13,14}$ Danazol yang semula dipakai untuk pengobatan endometriosis karena diduga bekerja secara hormonal, juga telah dipakai untuk mengobati penyakit autoimun.Oleh karena itu selain oleh efek hormonalnya, keberhasilan pengobatan danazol diduga juga oleh efek imunologik. Danazol mengurangi tempat ikatan IgG (reseptor Fc) pada monosit, sehingga mempengaruhi aktivitas fagositik sel-sel tersebut. Beberapa penelitian menemukan peningkatan IgM, IgG, serta Ig A dalam serum pasien endometriosis. ${ }^{15}$

\section{GEJALA KLINIS}

Endometriosis dapat ditemukan di berbagai tempat dan hal ini mempengaruhi gejala yang ditimbulkan. Tempat yang paling sering ditemukan di belakang kavum uteri, pada jaringan antara rektum dan vagina, dan permukaan rektum. Kadangkadang ditemukan juga di tuba Falopii, ovarium, otot-otot pengikat rahim, kandung kencing, dan dinding samping panggul. ${ }^{1-7}$

Setiap bulan jaringan endometriosis di luar kavum uteri mengalami penebalan dan perdarahan mengikuti siklus menstruasi. Perdarahan ini tidak mempunyai saluran keluar seperti darah menstruasi yang normal, tetapi terkumpul dalam rongga panggul dan menimbulkan nyeri. Jaringan endometriosis dalam ovarium menyebabkan terbentuknya kista coklat. Akibat inlamasi kronis pada jaringan endometriosis, terbentuk jaringan parut dan perlengketan organ-organ reproduksi. Sel telur sendiri terjerat dalam jaringan parut yang tebal sehingga tidak dapat dilepaskan. Sepertiga dari pasien endometriosis tidak memperlihatkan gejala apapun selain infertilitas. ${ }^{16}$

Gejala endometriosis bervariasi dan tidak bisa diprediksi. Nyeri haid (dismenorea), nyeri pinggang kronis, nyeri pada saat berhubungan (dispareunea), dan infertilitas merupakan gejala yang umum terjadi. Banyak pendapat yang dikemukakan berbagai peneliti mengenai nyeri yang timbul. Pada dasarnya, nyeri pada endometriosis muncul sebagai akibat materi 
peradangan yang dihasilkan oleh endometriosis yang aktif. Sel endometrium yang berpindah tadi akan terkelupas dan terlokalisasi di suatu tempat, selanjutnya merangsang respon inflamasi dengan melepaskan materi sitokin sehingga muncul perasaan nyeri. Selain itu, nyeri juga dapat ditimbulkan akibat sel endometrium yang berpindah tersebut menyebabkan jaringan parut di tempat perlekatannya dan menimbulkan perlengkatan organ seperti ovarium, ligamentum ovarium, tuba Fallopi, usus, dan vesika urinaria. Perlengketan ini akan merusak organ-organ tersebut dan menimbulkan nyeri yang hebat di sekitar panggul. ${ }^{16-19}$

Endometriosis ditemukan pada $25 \%$ wanita infertil, dan diperkirakan 50\%-60\% dari kasus endometriosis akan infertil. Endometriosis yang invasif akan mengakibatkan kemandulan akibat berkurangnya fungsi kavum uteri dan adanya perlengketan pada tuba dan ovarium. Terdapat beberapa teori yang mengemukakan bahwa endometriosis menghasilkan prostaglandin dan materi proinflamasi lainnya, yang dapat mengganggu fungsi organ reproduksi dengan menimbulkan kontraksi atau spasme. Juga dikemukakan bahwa pada endometriosis fungsi tuba Fallopi menjadi terganggu dalam hal pengambilan sel telur dari ovarium, bahkan dapat merusak epitel dinding kavum uteri dan menyebabkan kegagalan implantasi hasil pembuahan. Sebagai akibat, pasien dengan endometriosis memiliki riwayat abortus tiga kali lebih sering dari pada wanita normal. ${ }^{20,21}$

Gejala yang sering ditemukan ialah nyeri, pendarahan, serta keluhan pada saat buang air besar dan kecil. Hebatnya nyeri tergantung pada lokasi endometriosis, dapat berupa nyeri pada saat menstruasi, serta nyeri selama dan sesudah hubungan intim. Pendarahan bisa banyak dan lama pada saat menstruasi, berupa spotting sebelum menstruasi, menstruasi yang tidak teratur, dan darah menstruasi berwarna gelap yang keluar sebelum menstruasi atau di akhir menstruasi. Keluhan buang air besar dan kecil bisa berupa nyeri pada saat buang air besar, adanya darah pada feses, diare, konstipasi dan kolik, serta nyeri sebelum, pada saat, dan sesudah buang air kecil. ${ }^{20,21}$

\section{DIAGNOSIS}

Jaringan endometriosis tetap memiliki aktivitas sama dengan endometrium sesungguhnya sehingga akan terus aktif selama masih terdapat hormon di dalam tubuh. Setelah menopause, keluhan endometriosis akan menghilang, Gejala yang sering dijumpai ialah nyeri haid (dismenorea) yang terjadi 1-3 hari sebelum haid, dan dengan makin banyaknya darah haid yang keluar keluhan dismenorea akan mereda. ${ }^{6}$

Endometriosis pada ovarium akan menyebabkan terjadinya kista endometriosis. Bila ukuran kista endometriosis tersebut sudah $>5 \mathrm{~cm}$, sering menimbulkan gejala penekanan. Gejala-gejala lain yang mengarah pada endometriosis ialah infertilitas, nyeri pelvis, nyeri senggama, nyeri perut merata, nyeri suprapubik, disuria, hematuria, benjolan pada perut bawah, serta gangguan miksi dan defekasi. ${ }^{20,21}$

Pada pemeriksaan dalam kadang didapatkan benjolan-bejolan di kavum Douglasi, dan daerah ligamentum sakrouterina yang sangat nyeri pada penekanan. Uterus biasanya sulit digerakkan. Jika terdapat kista, di parametrium dapat teraba adanya massa kistik yang terasa nyeri bila disentuh. Bila terdapat kecurigaan endometriosis pelvis, dapat dilakukan laparoskopi atau juga dengan USG (Gambar 1) untuk menemukan massa kistik di daerah parametrium yang pada lapang pandang laparoskopi tampak pulau-pulau endometriosis berwarna kebiruan dan biasanya berkapsul. Pemeriksaan USG dapat dilakukan dengan mengikuti jalur algoritma (Gambar 1). ${ }^{22-25}$

Pemeriksaan laparoskopi sangat diperlukan untuk diagnosis pasti endometriosis agar dapat menyingkirkan diagnosis banding antara radang pelvis dan keganasan di daerah pelvis. USG transvaginal yang telah dikenal akurasinya, hanya sedikit membantu dalam menemukan massa kistik di daerah parametrium dengan gambaran 


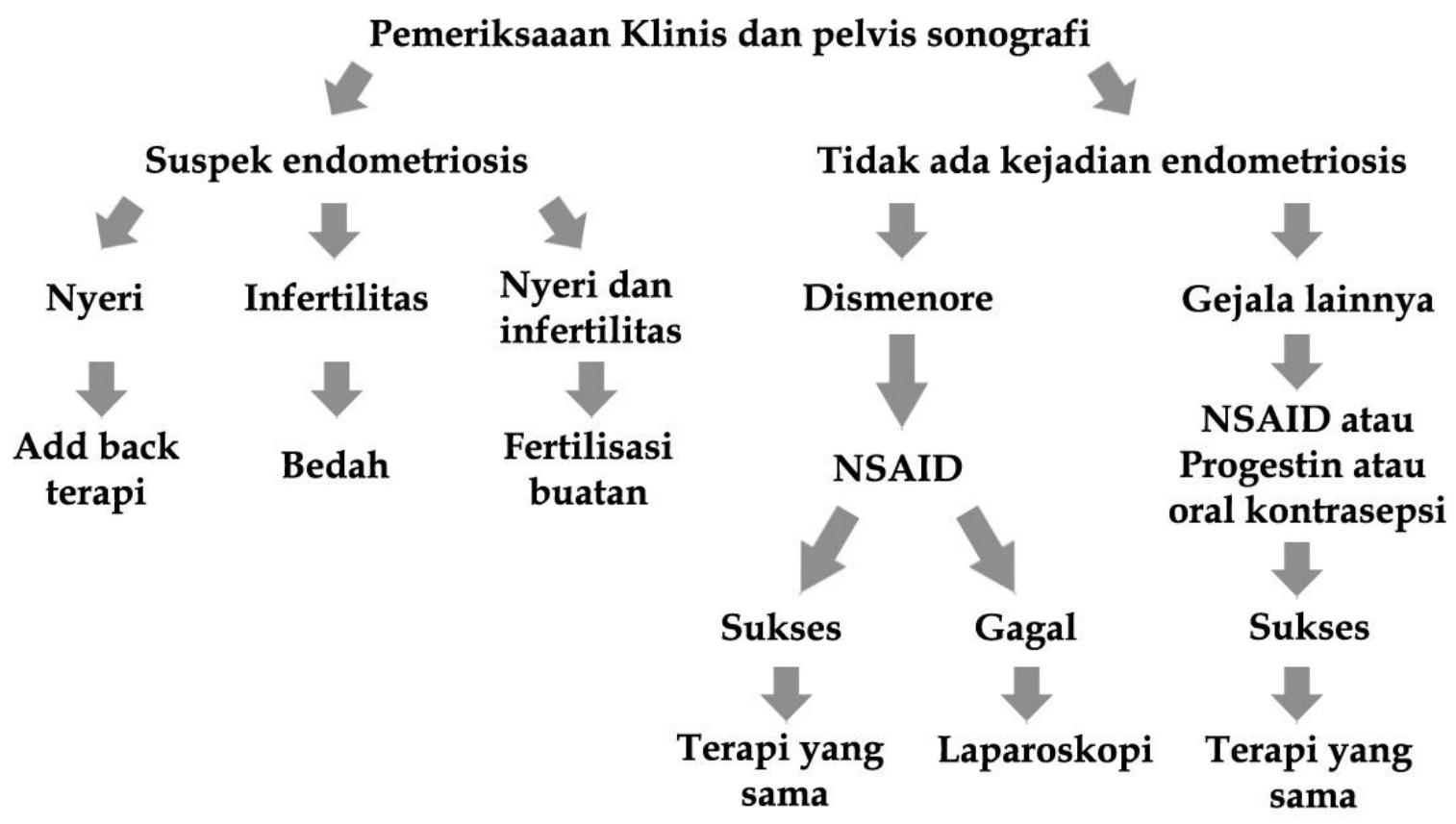

Gambar 1. Algoritma pemeriksaan klinis endometriosis dengan sonografi pelvis. ${ }^{22}$

sonolusen (hipoekhoik) dengan ekho dasar kuat tanpa gambaran yang spesifik untuk endometriosis (Gambar 1). ${ }^{22}$

\section{PENGOBATAN}

Berdasar prinsip umpan balik negatif, pengobatan endometriosis awalnya masih menggunakan estrogen. Dewasa ini, estrogen tidak terlalu disukai lagi dan mulai ditinggalkan. Efek samping yang ditimbulkan kadang-kadang dapat berakibat lanjut kematian. Salah satu efek samping yang sangat dikhawatirkan ialah terjadinya hiperplasia endometrium yang dapat berkembang menjadi kanker endometrium. ${ }^{26}$

Dari berbagai jenis hormon yang telah dipakai untuk pengobatan endometriosis dalam dua dasawarsa terakhir ini, ternyata danazol termasuk golongan hormon sintetik pria turunan androgen dengan substitusi gugus alkil pada atom C-17 ol. Efek antigonadotropin Danazol ini terjadi dengan cara menekan FSH dan LH, sehingga teriadi penghambatan steroidogenesis ovarium. Pemberian danazol mengakibatkan jaringan endometriosis menjadi atrofi dan diikuti dengan aktivasi mekanisme penyembuhan dan resorpsi penyakit. $^{27,28}$

Androgen dapat membebani fungsi hati; oleh karena itu danazol tidak dianjurkan pada pasien endometriosis dengan penyakit hati, ginjal, dan jantung. Selain itu, hormon ini juga termasuk hormon pria sehingga efeknya tidak terlalu nyaman bagi wanita. Danazol juga kadangkadang menyebabkan perdarahan bercak (spotting) yang tidak menyenangkan. Dewasa ini dipakai preparat medroksi progesteron asetat (MPA) dan didrogesteron. Kedua senyawa ini merupakan progesteron alamiah dengan efek samping yang tidak separah danazol. Bentuk yang tersedia berupa paket komposit, jadi satu tablet dapat terdiri dari beberapa jenis obat. ${ }^{15,29}$

Mengingat endometriosis dapat menyebabkan infertilitas, pengobatan endometriosis pada pasien dengan infertilitas harus mendapatkan perhatian. Pilihan pengobatan endometriosis pada kasus infertilitas belum seragam dan bergantung pada beberapa faktor, yaitu usia, luasnya endometriosis, luas dan lokasi perlekatan pelvik, dan faktor-faktor infertilitas secara bersamaan. Kepastian diagnosis endometriosis 
harus dibuat pada saat laparoskopi atau laparotomi; oleh karena itu rencana pengobatan juga harus dirancang dan dimulai di meja operasi. Dengan adanya perkembangan pesat berbagai tehnik pengobatan, termasuk elektrokauter, laser, dan laparoskopi operatif, maka semua susunan endometriosis yang tampak pada saat laparoskopi awal kini telah mampu diablasi. ${ }^{22,27}$

Pada endometriosis derajat berat dan luas, pembedahan atraumatik merupakan pilihan utama karena sudah diketahui bahwa endometrioma yang lebih besar dari 1 $\mathrm{cm}$ tidak menyusut selama pengobatan medikamentosa. Pengangkatan endometrioma saat operasi dilakukan karena faktorfaktor mekanik antara lain perlekatan yang mengganggu mekanisme penangkapan ovum hanya dapat ditanggulangi dengan pembedahan; oleh karena itu, sekuele endometriosis merupakan indikasi primer untuk pembedahan. $^{30}$

Pada endometriosis derajat minimal, pengamatan dan sikap menunggu sering menghasilkan kehamilan. Pada derajat ringan, pengobatan medikamentosa merupakan pilihan. Bila endometriosis ringan terjadi bersamaan dengan faktor-faktor infertilitas lainnya, hasil yang baik akan diperoleh dengan memperbaiki faktorfaktor infertilitas tersebut. Pada endometriosis ringan, bila disertai anovulasi, luteinized unruptured follicle (LUF), defek fase luteal, serta hiperprolaktinemia hendaknya hal-hal tersebut diperbaiki terlebih dahulu. Bila pendekatan demikian tidak menghasilkan kehamilan dalam waktu dekat, maka endometriosisnya harus diobati terlebih dahulu. ${ }^{30-32}$

Dengan mikroskop elektron akan terlihat bahwa lesi endometriosis yang sederhana biasanya terpencar pada permukaan peritoneum sebagai polip-polip kecil atau bongkah-bongkah berdiameter $<1 \mathrm{~mm}$. Lesi endometriosis ini tidak dapat dilihat dengan mata telanjang atau dengan laparoskopi saja. Lesi ini juga tidak dapat dirusak dengan pembedahan atau koagulasi. Meskipun belum terlihat adanya destruksi sempurna, lesi-lesi demikian dapat menyusut selama pengobatan medikamentosa; oleh karena itu kombinasi obat-obatan dengan pembedahan harus beriringan. $^{32}$

Skema pengobatan endometriosis disusun berdasarkan gejala yang paling utama dikeluhkan oleh pasien. Nyeri dan infertilitas merupakan gejala yang paling sering dikeluhkan oleh pasien endometriosis.

\section{Keluhan nyeri}

Nyeri merupakan keluhan yang paling banyak dirasakan oleh penderita endometriosis; walaupun demikian patofisiologi nyeri belum jelas dipahami. Heterogenitas dari proses penyakit ini menyebabkan kesulitan memastikan etiologi nyeri yang sebenarnya. Terdapat teori yang mengemukakan bahwa jenis lesi yang berbeda akan menyebabkan timbulnya rasa nyeri dengan cara yang berbeda. ${ }^{16-19}$

Lesi awal endometriosis mengandung kadar prostaglandin yang lebih tinggi dibandingkan dengan lesi yang lebih tua. Prostaglandin ini akan mengaktifkan jalur saraf aferen. Lesi yang terletak lebih dalam pada peritoneum juga meningkatkan rasa nyeri. Perlekatan dan fibrosis juga menyebabkan rasa nyeri yang berhubungan dengan pasokan darah pada pleksus saraf atau menyebabkan terjadinya peregangan serabut saraf pada jaringan dan mengakibatkan nyeri. Iritasi langsung pada jaringan saraf sekitarnya akibat infiltrasi lesi juga menyebabkan nyeri. Penelitian terhadap pemberian agonis GnRH, danazol, dan kontrasepsi oral ternyata cukup memuaskan untuk mengurangi keluhan nyeri. Terapi hormonal di atas terutama dengan agonis GnRH harus diikuti dengan pemberian add back therapy untuk mengurangi komplikasi yang ditimbulkan akibat pemberian agonis GnRH yang lama. Beberapa penelitian mengemukakan bahwa add back therapy tidak akan memperberat keluhan nyeri.

Tindakan bedah dapat dilakukan jika pemberian terapi medikamentosa untuk mengatasi keluhan nyeri tidak memberikan hasil yang berarti. Tindakan bedah yang 
dilakukan mencakup ablasi lesi endometriosis, lisis dari pelekatan, dan neurektomi nervus uterosakral. ${ }^{17}$

\section{Infertilitas}

Endometriosis sedang dan berat, khususnya bila telah terdapat pelekatan pada ovarium dan tuba Falopii, akan menurunkan angka kejadian fertilisasi. Hal ini terjadi karena adanya obstrusi mekanik dari ovarium dan tuba Falopii yang menyebabkan gagalnya transpor gamet ke pars ampularis tuba Falopii. Walaupun belum ada penelitian yang memperlihatkan perbedaan kejadian fertilitas antara yang telah dilakukan tindakan dan tanpa tindakan, banyak publikasi yang menunjukkan angka kejadian fertilitas nol untuk yang mengalami endometriosis berat. Ternyata tindakan pembedahan dapat meningkatkan kejadian kehamilan pada pasien endometriosis sedang dan berat. ${ }^{20,21}$

Pada kasus endometriosis minimal dan ringan ternyata tetap terdapat hubungan antara kejadian endometriosis dengan gangguan reproduksi, walaupun hubungan ini belum terlalu jelas. Teori mengenai patofisiologi gangguan tersebut mencakup gangguan ovulasi, gangguan pematangan oosit, gangguan terhadap sperma di rahim, toksisitas embrio, abnormalitas sistem imun, dan gangguan penerimaan endometrium terhadap implantasi embrio. ${ }^{33-36}$

Induksi ovulasi pada kasus endometriosis ternyata memberikan hasil yang cukup memuaskan. Penelitian randomized trials memperlihatkan pemberian agonis GnRH dengan hormon FSH dan LH, klomifen sitrat, serta inseminasi intrauterin, atau FSH dengan inseminasi intrauterin memperlihatkan peningkatan angka kehamilan dibandingkan pada yang tanpa terapi. Tindakan assited reproductive technology (ART) masih dapat dilakukan pada kasus endometriosis berat. ${ }^{37,38}$

\section{Kehamilan setelah pengobatan endo- metriosis}

Endometriosis mengakibatkan intertilitas gangguan ovulasi, perlengketan jaringan, penyumbatan tuba Falopii, kehamilan ektopik, dan penyebab lain yang tidak diketahui. Keberhasilan kehamilan setelah pengobatan dengan pembedahan dan terapi hormon berkisar $40-70 \%$, tergantung pada beratnya endometriosis. ${ }^{37}$ Untuk mengupayakan kehamilan setelah pengobatan endometriosis dapat dilakukan dengan menunggu, induksi ovulasi, inseminasi intra uterin, atau in vitro fertilization.

\section{Cairan peritoneal}

Pada keadaan tanpa perlekatan atau kelainan anatomi dan endometriosis yang ada hanya berupa lesi sangat kecil di kavum Douglasi, kemungkinan terjadinya kehamilan spontan sangat besar. Infertilitas akibat endometriosis murni disebabkan faktor mekanis yang membuat ovum atau sperma rnengalami hambatan pasase. ${ }^{35}$

Pada endometriosis ringan yang tidak melibatkan ovarium dan terbatas pada peritoneum pelvis, lebih diutamakan pengobatan hormonal selama enam bulan. Bila terjadi fibrosis dan perlekatan yang mengakibatkan fiksasi ovarium ke ligamentum latum posterior, maka keadaan ini dapat menyebabkan kerusakan arsitektur tuba yang tidak dapat dikembalikan hanya dengan pengobatan hormonal. Bila pasien tidak tahan terhadap pengobatan hormonal atau gejalanya kambuh kembali, tentu diperlukan pembedahan konservatif. Bila pasien belum hamil dalam selang waktu yang diperkirakan, pembedahan konservatif diharapkan dapat memberikan harapan yang lebih besar untuk terjadinya kehamilan. Bila endometriosis tidak dapat dikeluarkan secara baik, terapi medikamentosa dapat diberikan penuh selama satu tahun pascabedah. ${ }^{39}$

Tennik pendekatan yang lebih baik dan rasional yaitu dengan memperhatikan interaksi faktor lokal yaitu cairan peritoneal dan faktor sistemik secara imunoendokrinologik dan selular, berhubung telah ditemukan bentuk baru endometriosis yang tak terdeteksi dengan laparoskopi. Bentuk ini dikenal sebagai endometriosis biokimia- 
wi. Perlu dipikirkan pengobatan terhadap cairan peritoneum karena lesi peritoneum dari endometriosis berhubungan langsung secara bebas dengan rongga peritoneum dan menyekresikan produknya secara langsung pula ke dalam cairan peritoneum.

\section{SIMPULAN}

Sampai sekarang ini patofisiologi endometriosis belum jelas dipahami. Keluhan yang sering muncul yaitu nyeri saat haid dan inferfilitas, sulit untuk diobati karena tidak banyak opsi pengobatan yang dapat ditawarkan kepada pasien.

Untuk keluhan utama nyeri, terapi lini pertama yang diberikan ialah NSAID atau kontrasepsi oral. Bila terapi konservatif ini gagal, dua terapi alternatif dapat dicoba yaitu terapi empirik agonis $\mathrm{GnRH}$ dikombinasi dengan estrogen dan progestin add-back therapy, atau laparoskopi operatif. Tindakan laparoskopi harus mencakup lisis dari perlekatan dan eksisi endometriosis dengan atau neurektomi presakral, tergantung pada lokasi dari nyeri dan pengalaman dari ahli bedah saraf.

Induksi ovulasi pada kasus endometriosis memberikan hasil yang cukup memuaskan. Pemberian GnRH agonis dengan hormon FSH dan LH, klomifen sitrat, serta inseminasi intrauterin, atau FSH dengan inseminasi intrauterin memperlihatkan peningkatan kejadian kehamilan dibandingkan dengan kasus yang tanpa terapi.

\section{DAFTAR PUSTAKA}

1. Speroff L, Fritz M. Clinical Gynecologic Endocrinology and Infertility. Philadelphia: Lippincott Williams \& Wilkins, 2005.

2. Bulun SE. Endometriosis. N Engl JMed 2009;360:268-79.

3. Kennedy $\mathbf{S}$. The patient's essential guide to endometriosis [homepage on the Internet]. Nodate [Cited 2012 Aug 9]. Available from: http://www.endo metriosiszone.org/display.asp?page =Endometriosis_essential_guide
4. Germaine BL, Hediger M, Peterson M, Croughan M, Sundaram R, Stanford $J$, et al. Incidence of endometriosis by study population and diagnostic method: The ENDO study [homepage on the Internet]. Nodate [Cited 2012 Aug 9]. Available from: http://www.ncbi. nlm.nih.gov/pmc/articles/PMC3143 230/.2012

5. Kim AH, Adamson GD. Endometriosis. In: Edlich RF, editor. Advances in Medicine. Arlington: ABI Professional Publications, 2000; p. 611-22.

6. American Society for Reproductive Medicine. Revised American Society for Reproductive Medicine classification of endometriosis 1996. Fertil Steril. 1997;67:817-21.

7. Witz CA, Schenken RS. Pathogenesis of endometriosis. In: Speroff L, Adamson GD, editors. Seminars in reproductive endocrinology. New York: Thieme; 1997;15(3):199-208.

8. Reid GD. Endometriosis and infertility. e-Report. 2005;1:1-5.

9. Cramer DW, Missmer SA. The epidemiology of endometriosis. Ann NY Acad Sci. 2002;955:11-22.

10. Taylor R. Endometriosis. In: Berger GS, Nezhat FR, Buttram VC, Nezhat $\mathrm{CH}$, editors. Advanced Management and Surgical Techniques. New York: Springer-Verlag, 1995; p. 19-25.

11. Lebovic DI, Mueller MD, Taylor RN. Immunobiology of endometriosis. Fertil Steril. 2001;75:1-10.

12. Pittaway DE, Fayez JA. The use of CA-125. In: The diagnosis and management Of endometriosis [homepage on the Internet]. Nodate [Cited 2012 Sept 12]. Available from: http://www.ejwm.org/search.php?w here=aview\&id=10.5468/jwm.2010. 3.3.108\& code $=0637 \mathrm{JWM} \&$ vmode $=$ AR

13. Evers JLH. The defense against endometriosis. Fertil Steril. 1996;66:351.

14. Gebel HM, Braun DP, Tambtjr A, Frame D. Rana N, Dmowski WT. 
Spontaneous apoptosis of tissue is impaired in women with endometriosis. Fertil Steril. 1998;69:1042-4.

15. Selak V, Farquhar C, Prentice A, Simla A. Danazol for pelvic pain associated with endometriosis [homepage on the Internet]. Nodate [Cited 2012 Aug 13]. Available from: https://science.nichd.nih.gov/ confluence/download/attachments/3 2932397/ASRM+Treatment_of_pel vic_pain.pdf.2012

16. Olive DL, Black-well RE, Copperman AB. Endometriosis and pelvic pain. In: Blackwell RE, Olive DL, editors. Chronic Pelvic Pain: Evaluation and Management. New York: Springer, 1997; p. 61-83.

17. Palter SF. Office-based surgery and its role in the management of pelvic pain. In: Black-well RE, Olive DL, editors. Chronic Pelvic Pain: Evaluation and Management. New York: Springer-Verlag, 1998; p. 167-82.

18. American Congress of Obstetricians and Gynecologists. Pain Management of Endometriosis [homepage on the Internet]. Nodate [Cited 2012 Sept 13]. Available from: http:// www.acog.org/About_ACOG/News _Room/News_Releases/2010/Pain_ Management_of_Endometriosis.

19. Alford C, Taylor R, DeCherney A. Endometriosis [homepage on the Internet]. Nodate [Cited 2012 Sept 13]. Available from: http://www. endotext.org/female/female9/female frame9.htm.

20. Buyalos RP, Agarxval SK. Endometriosis-associated infertility. Curr Opin Obstet Gynecol 2000:12:37781.

21. Panidis DK, Matalliotakis IM. Subfertility associated with minimal to mild endometriosis main mechanisms. J Reprod Med. 1998: 43:1034-42.

22. Adamson GD. Laparoscopic treatment of endometriosis. In: Adamson GD, Martin DC, editors. Endoscopic Management of Gynecologic Dise- ases. Philadelphia: Lippincott-Raven Publishers; 1996:147-87.

23. Marcoux S, Maheux R, Berube $S$. Laparoscopic surgery in infertile women with minimal or mild endometriosis. N Engl J Med. 1997; 337(4):217-22.

24. Adamson GD, Hurd SJ, Pasta DJ, Rodriguez BD. Laparoscopic endometriosis treatment: is it better? Fertil Steril. 1993;59:35-44.

25. Osuga Y. Koga K, Tsutsumi O, Yano T, Maruyarna M, Kugu K, et al. Role of laparoscopy in the treatment of endometriosis-associated infertility. Gynecol Obstet Invest. 2002; 53:333-9.

26. Schenken R. Pathogenesis, clinical features, and diagnosis of endometriosis [homepage on the Internet]. Nodate [Cited 2012 Sept 13]. http://www.uptodate.com/contents/p athogenesis-clinical-features-anddiagnosis-of-endometriosis.

27. David L, Elizabeth A. Treatment of Endometriosis [homepage on the Internet]. Nodate [Cited 2012 Sept 14]. Avaliable from: http://www. nejm.org/doi/full/10.1056/NEJM200 107263450407.

28. Olive DL, Pritts EA. The treatment of endometriosis: a review of the evidence. Ann NY Acad Sci. 2002; 995:360-372.

29. Prentice A, Deary AJ, Bland E. Progestagens and anti-progestagens for pain associated with endometriosis [homepage on the Internet]. Nodate [Cited 2012 Sept 14]. Available from: http://www. ncbi.nlm.nih.gov/pubmed/10796864

30. Wood C, Maher P, Hill D. Diagnosis and surgical management of endometriomas. Aust NZ J Obstet Gynaecol. 1992;32:161-3.

31. Parazzini F. Ablation of lesions or no treatment in minimal-mild endometriosis in infertile women: a randomized trial. Gruppo Italiano per lo studio dell'endometriosi. Hum Reprod. 1999:14:1332-34. 
32. Falcone T, Goldberg JM, Miller KF. Endometrosis: medical and surgical interventions. Curt Opin Obstet Gynecol. 1996;8:178-83.

33. Proctor NIL, Latthe PM, Farquhar CM, Khan KS, Johnson NP. Surgical interruption of pelvic nerve pathways for primary and secondary dysmenorrhoea [homepage on the Internet]. Nodate [Cited 2012 Sept 14]. Available from: http://www. ncbi.nlm.nih.gov/pubmed/16235288

34. Dmowski VNT, Rana N, Michalowska J, Friberg J, Paplernjak C, el-Roeiy A. The effect of endometriosis, its stage and activity, and of autoantibodies on in vitro fertilization and embryo transfer success rates. Fertil Steril. 1995;63:555-62.

35. Pellicer A, Navarro J, Bosch E, Garrido N, Garcia-Velasco, Remohi J, et al. Endometrial quality in infertile women with endometriosis. Ann NY Acad Sci. 2001; 943:122-30.
36. Dokras A, Olive DL. Endometriosis and assisted reproductive technologies. Clin Obstet Gynecol. 1999; 42:687-98.

37. Olive DL, Kee KL. Analysis of sequential treatment protocols for endometriosis associated infertility. Am J Obstet Gynecol. 1986; 154:613-9.

38. Adamson GD, Pasta DJ. Surgical treatment of endometriosis-associated infertility: meta-analysis compared with survival analysis. Am J Obstet Gynecol. 1994;171(6):1488.

39. Vercammen EE, D'Hooghe TM. Endometriosis and recurrent pregnancy loss. Semin Reprod ed 2000; 18:363-8.

40. Surrey ES. Add-back therapy and gonadotropin-releasing hormone agonists in the treatment of patients with endometriosis; can a consensus be reached? [homepage on the Internet]. Nodate [Cited 2012 Sept 15]. Available from: http://www. ncbi.nlm.nih.gov/pubmed/10065775 